\title{
"Infrastructural geopolitics" of climate knowledge: the Brazilian Earth System Model and the North-South knowledge divide
}

\section{Jean Carlos Hochsprung Miguel* (1)}

\author{
Martin Mahony** (1)
}

Marko Synésio Alves Monteiro*** (i)

\begin{abstract}
This article examines how geopolitics are embedded into the efforts of Southern nations that try to build new climate knowledge infrastructures. It achieves this through an analysis of the composition of the international climate modelling basis of the Intergovernmental Panel on Climate Change (IPCC), viewed from the perspective of the Brazilian Earth System Model (BESM) - the scientific project which placed a Latin American country for the first time inside the global modelling bases of the IPCC. The paper argues that beyond the idea of "infrastructural globalism", a historical process of global scientific cooperation led by developed countries, we also need to understand the "infrastructural geopolitics" of climate models. This concept seeks to describe the actions of developing countries towards minimizing the imbalance of global climate scientific production, and how these countries participate in global climate governance and politics. The analysis of the construction of BESM suggests that national investments in global climate modelling were aimed at attaining scientific sovereignty, which is closely related to a notion of political sovereignty of the nation-state within the international regime of climate change.
\end{abstract}

Keywords: Climate change knowledge, IPCC, Climate modelling, Global South.

* Federal University of São Paulo, São Paulo, SP, Brazil.

** University of East Anglia, Norwich, United Kingdom

*** University of Campinas, Campinas, SP, Brazil. 


\section{"Geopolítica infraestructural" del conocimiento climático: el Modelo Brasileño del Sistema Terrestre y la brecha de conocimiento norte-sur ${ }^{\diamond}$}

\section{Resumen}

Este artículo examina cómo la geopolítica se integra en los esfuerzos de las naciones del sur que intentan construir nuevas infraestructuras de conocimiento sobre el clima. Lo logra a través de un análisis de la composición de la base internacional de modelos climáticos del Panel Intergubernamental sobre Cambio Climático (IPCC), visto desde la perspectiva del Modelo Brasileño del Sistema Terrestre (BESM), el proyecto científico que por primera vez colocó a un país latinoamericano en las bases de modelado global del IPCC. Se argumenta que, más allá de la idea del "globalismo infraestructural", un proceso histórico de cooperación científica global liderado por países desarrollados, también necesitamos entender la "geopolítica infraestructural" de los modelos climáticos. Este concepto busca describir las acciones de los países en desarrollo para minimizar el desequilibrio de la producción científica sobre el clima, y cómo estos países participan en la gobernanza y política climática global. El análisis de la construcción de BESM sugiere que las inversiones nacionales en modelos climáticos globales tenían como objetivo alcanzar la soberanía científica, que está estrechamente relacionada con una noción de soberanía política del Estado-nación dentro del régimen internacional de cambio climático.

Palabras clave: Conocimiento del cambio climático, IPCC, Modelado climático, Sur global.

\section{Introduction}

n this paper we argue that climate knowledge infrastructures can be closely related to the geopolitical dimensions of the climate change regime. We focus on how developing and developed countries relate to each other in the composition of the scientific basis for the Intergovernmental Panel on Climate Change (IPCC). In his comprehensive book A Vast Machine, Paul Edwards (2010) presents a historical account of climate science as a global knowledge infrastructure. Edwards emphasizes the "globalist" character of scientific progress, describing a process of co-evolution of scientific knowledge, its infrastructures and political institutions like the World Meteorological Organization (WMO) and the IPCC. Nevertheless, the 
construction of a global climate knowledge infrastructure involves different scientific groups from different national, cultural, and socioeconomic realities.

As Shackley (2001) points out, the "epistemic lifestyle" of climate scientists can vary from country to country and reflect important cultural and institutional dimensions. However, Shackley - like Edwards - focuses on the realities of Euro-American climate science groups, with this and related work largely overlooking the climate knowledge infrastructures of the so-called "global South". A number of important questions remain unexplored, like what kinds of asymmetries exist between climate science groups in developed and developing countries, what kinds of strategies have been applied to overcome difficulties in the production of climate scientific knowledge in developing countries, and how do these different "worlds" of climate science relate to each other in "globalist" spaces like the IPCC?

The IPCC is the institution that sets the scientific parameters for international discussion on climate change; it is an intergovernmental agency under the United Nations Environment Programme and the WMO, composed of scientists from 193 member nations. The IPCC seeks to summarize the state of the art of the scientific understanding of climate change and provide informed advice to policymakers through official assessment reports that represents the consensus view of the leading climate change experts in the world (IPCC, 2013).

However, since its beginning in 1988, critical analysis of the expertise mobilized in IPCC assessments has highlighted the lack of participation of developing country experts (Hulme; Mahony, 2010). For example, Kandlikar and Sagar (1999) examined the IPCC First and Second Assessment Reports with respect to the participation of Indian expertise and found the participation "heavily skewed in favour of some industrialized countries" (Kandlikar; Sagar, 1999, p. 134). Lahsen, in her study of Brazil and the climate change regime argues: "Brazilian climate scientists reflect some distrust of the IPCC, which they describe as dominated by Northern framings of the problems and therefore biased against interpretations and interests of the South" (Lahsen, 2004, p.161). Mahony (2014) discusses the occasionally antagonistic relationship between the Panel and Indian political and scientific communities, bringing to light something of the geopolitics of climate 
knowledge production. These cases illustrate the agonistic coexistence of different "worlds" in the IPCC which can be expressed in the Global North and Global South framework (Joshi et al., 2013).

The emergence of the notions of Global North and Global South can be traced to early political negotiations around environmental change and refers back to the historical trajectories of different (rich/poor, postimperial/post-colonial, developed/developing) parts of the world ${ }^{1}$. In this article, the North/South distinction will be used to emphasize asymmetries in climate knowledge production between geographical regions composed by developing and developed countries ${ }^{2}$. At the same, we attend to how this North/South distinction is mobilized by scientific and politics actors in support of different positions and courses of action.

Investigating the case of the Brazilian Earth System Model (BESM) - the scientific project which placed a Latin American country for the first time inside the global modelling bases of IPCC - this article analyses the dynamic constitution of the central and peripheral dimensions of global climate science and interprets the asymmetries of resources and power that remain within the IPCC scientific network. While the notion of "infrastructural globalism" is important for comprehending the rise of a global knowledgemaking enterprise, it is less useful in comprehending the different realities of developed and developing countries and how the science produced by them participates in the IPCC. In this paper we seek to uncover the politics of climate science in the international climate change regime, and the geopolitics of generating climate knowledge on the "Southern" side of the global climate knowledge infrastructure. Beyond infrastructural globalism, we need to understand the "infrastructural geopolitics" of global climate knowledge between developing and developed nations, if we are

\footnotetext{
1Harding (2015) explains that the term "Global South" was invented by activists at the 1992 United Nations environment conference in Rio de Janeiro to designate issues related to globalization that hide histories of colonialism and North-controlled development policies. ${ }^{2}$ However, it is important to recognize that there is the problem that the use of these binaries terms overemphasizes a supposed homogeneity of each side and undervalues the hybrid, interactive nature of so much of the global social relations (Mac Leod, 1982). On the other hand, avoiding these dichotomies, there is the risk of completely diluting the central and peripheral dimensions and the deep asymmetries of resources and power that remain in the global scientific networks (Kreimer, 2016).
} 
to understand the asymmetries and different political perspectives involved in the production of global climate knowledge.

Beyond the processes of inclusion of authors and peer-reviewers from developing countries in the IPCC, attention is needed to the different national production sites and infrastructures of the primary knowledge being assessed: the exclusive network of climate modelling centres that exert power over descriptions of future climate. Among the various methods, instruments and practices that are part of atmospheric science routines and climate policy, numerical models and advanced computational infrastructures have played a central role.

Computational models are the main tools with which the atmospheric sciences perform meteorological forecasts and global climate studies (Shackley et al., 1998, Lahsen, 2005; Wynne, 1996; 2010; Edwards, 2010). These models, often referred to as "climate models," are present in the daily routines of weather forecasting centres and substantially in the reports of important international scientific organizations such as the IPCC, whose reports have been the basis of discussions on international political agreements (Demerrit, 2001; Hulme; Mahony, 2010). Climate modelling has thus emerged as a fundamental organizational principle for the global epistemic community that surrounds climate issues (Sudenberg, 2007a; 2007b; Duarte, 2016), also becoming a central actor in global climate governance regimes. A process of mutual reinforcement can be observed models reinforce the authority of policymakers, and in turn, the hegemony of computational simulation as a way of producing knowledge about the global climate is secured (Shackley, 1997; Hulme, 2013).

Nevertheless, global climate models are tools developed by a small number of countries with the financial and technical capacity to practice this kind of science. Historically, the United States, Europe and Japan have hosted most of the climatological centres that develop global climate models (Edwards, 2010). It is also these countries that are largely responsible for producing the simulations that define the emission scenarios for IPCC Working Group $1^{3}$. Therefore, IPCC climate futures have been largely defined

${ }^{3}$ Considered the "science group", the group of earth and natural sciences that construct the basis of the IPCC report. 
by the climate science produced by countries of the "Global North". Only recently have Global South countries begun to address this imbalance, with Brazil having a privileged position through investing in larger-scale scientific infrastructure for climate research ${ }^{4}$.

To discuss the geopolitical implications of "Global South" climate modelling infrastructures, this paper analyses the history of the Brazilian Earth System Model (BESM). From the perspective of Science and Technology Studies (STS) we show how BESM is shaped by political, institutional, cultural and material elements, having also become important to how Brazil has positioned itself in the global geopolitics of climate change. Through describing the local conditions and negotiations of the climate modelling group BESM, we analyse how the "elite" world of global climate simulation is composed and how this is perceived by Southern modelers and leading climate science researchers in Brazil.

This paper is based on four years of fieldwork (between 2013 and 2016) on the organization of meteorology in Brazil and the history of numerical weather prediction (Miguel, 2017). This included conducting twenty-nine interviews with key informants of the Brazilian National Institute for Space Research (INPE) - the main institution of climate modelling development in the country - and attending scientific events in the area of climate modelling and climate change in Brazil. In addition, relevant documents and news media were collected and analysed. The empirical material was subject to interpretive content analysis drawing on the tools of grounded theory (Charmaz, 2006).

\footnotetext{
${ }^{4}$ It should be mentioned that this article is published at a transition towards potentially much less influence of Brazilian science in the IPCC and the global governance of climate and environment. Due to severe budget cuts in science funding (Angelo, 2019); a national agenda that is explicitly averse to global environmental regimes and is reverting Brazil's leadership in that realm (Abessa; Famá; Buruaem, 2019); and also an ideologically charged foreign policy which equates global institutions and climate change to "a Marxist plot" (Watts, 2018). The recent institutionalizing of the distorted idea of globalism as equal to leftist conspiracy against Brazil promises to potentially shift the country to a very different position in the global climate regimes in the next years.
} 


\section{The geopolitical dimensions of climate knowledge infrastructures}

Knowledge infrastructures increasingly are used in politics, and this can also be seen on a global scale, as the example of global climate governance makes clear. Understanding how such infrastructures participate in global fluxes of politics and power demands a conceptualization of how infrastructures are then a part of geopolitics, especially as such infrastructures are permeated by asymmetries related to who owns which capacities, and thus who can speak on climate in different ways. Conceptualizing climate geopolitics thus should include a reflection on how technological infrastructures not only become conditioned by such politics: they are also part of what makes these geopolitics possible in the first place, having a role in defining and sustaining power imbalances. Therefore, actions and disputes in and around the building and maintenance of such infrastructures are important to understanding global geopolitical dimensions of both climate governance and knowledge infrastructures.

STS has shown that infrastructures, more than a collection of artifacts or a "technology", should be thought of as a system of objects and relationships between technologies, people and material objects. Infrastructures are thus entwined with cultural habits, with social and economic organizations, with professional and personal identities, and so on (Jackson et al., 2007; Jensen; Winthereik, 2013). Andrew Barry (2013) suggests that infrastructures, material artefacts, and physical systems are objects and environments that should be understood as integral to the conduct of state politics and international relations. According to him, material objects and infrastructures never exist in isolation, but are themselves "evolving entities" that form part of a constellation of dynamic social relations. He emphasizes that building infrastructures is a way of maintaining or transforming certain power relationships. Infrastructures can therefore be interpreted as "political machines" (Barry, 2013), situated within different arrangements of power and authority.

The climate change regime is a complex arrangement of power and authority that links the microsocial contexts in which knowledge about the environment is produced (in scientific laboratories, field experiments, and 
climate modelling centres) with the macropolitical and economic institutions that shape social and environmental change on a global scale (Miller; Edwards, 2001). Climate knowledge infrastructures have been historically deeply involved in national and international political contexts. Formalized systems for observing and predicting weather and climate originated in the national weather services of the nineteenth century, largely to support military operations (Fleming, 2016). Initially, national weather services were operated as largely separate systems, but soon their data reporting became linked through coordinated international networks, a process that Paul Edwards (2006) calls "voluntaristic internationalism". Cooperation and coordination were there for those who wanted it, but there was no compulsion for countries to participate.

This changed in the immediate post-war period, when the WMO emerged as a force to bind countries into global cooperation. Edwards (2010, p. 18) argues that the "building of technical systems for gathering global data helped to create global institutions and ways of thinking globally". Post-war infrastructural globalism in meteorology and related sciences was a key agent of both technical and cultural globalization. He offers the image of "a vast machine" to refer to the global knowledge infrastructure which emerged in climate science - a planet-girdling network of instruments, satellites, data connections, code and computational models which offered a radically new way of picturing and comprehending global systems and, crucially, global change. The "infrastructural globalism" of meteorology and climate science undergirds global intergovernmental organizations such as the WMO and the IPCC, a process that interlinks scientific and political affairs in an unprecedented process of international cooperation.

This "infrastructural globalism" is a key site where science and politics are co-produced. Clark Miller (2001) shows how the ability of scientists to produce knowledge about global-scale natural phenomena has rested on their ability to shape appropriate political as well as scientific institutions. Governments had to be persuaded to provide the necessary resources to construct, maintain, and operate the meteorological network. Miller emphasizes that "meteorologists needed to convince sceptical governments and publics that scientific and technical cooperation of the form they offered 
would bring benefits beyond scientific knowledge for its own sake" (Miller, 2001, p. 169). The formation of scientific spaces can only be achieved by connecting them with national and international affairs.

A key question is how different scientific groups act to connect science and policy in different national contexts, and how these connections add up to create a global infrastructure. Elzinga (1993) suggests that, in international environmental affairs (like climate change), science is frequently "politics by other means". Analysing the emergence of global environmental research programs, he emphasizes that the desires of national scientific groups to be part of the agendas of international scientific programs can only be fulfilled through trade-offs with national political groups. On the one hand, research groups receive public funds to develop their research; on the other, by conducting their research and gradually obtaining international scientific recognition, scientific groups carry out a political task through science which allows advancing the international interests of geopolitical arenas. Elzinga (1993) clarifies that such a correlation between science and geopolitics is possible because scientific research has two types of values that are associated: a) the "practical instrumental" - related to the ability to solve concrete problems through the application of scientific knowledge; and b) the "symbolic instrumental" - related to the emblem of scientific capacity as a symbol of power, social advancement and development. With these two modes of power, scientific knowledge is an effective means of meeting national objectives and geopolitical goals in international arenas.

Through the operation of global climate knowledge infrastructures and networks such as the IPCC, climate change is framed in relation to specific questions of political economy, and in ways which pose questions of how nation-states can respond and adapt to climate change as matters of security and sovereignty (O'Lear; Dalby, 2015). Considered one of the main scientific resources to guide plans of climate change adaptation, climate modelling offers a power of calculation and a capacity to predict the imbrications of climate and national territories in the future (Mahony; Hulme, 2012; Mahony, 2014). As political machines, climate models exercise both practical and symbolic power in the construction of what political geographers have described as a new form of 'geo-metrics' (Elden, 2013; 
Dalby, 2013): those "calculative strategies turned towards land, terrain and territory", albeit at increasingly global or even post-national scales, which offer to political actors important glimpses into the future, and "means of comprehending and compelling, organizing and ordering" (Elden, 2013, p. 49). As Dalby (2013, p. 40) points out, as climate change "becomes a more high-profile concern for global governance, the crucial measurements of the earth, its geometrics, are key to geopolitical considerations." Attending to how climate models are constructed and used by different national scientific groups, and how they are interlinked with geopolitics, is a topic that nonetheless remains largely underexplored.

\section{Global climate modelling groups between North and South}

Numerical modelling of Earth's climate is a science that has evolved since the 1950s and has been boosted by different technical developments, including more powerful calculation methods and the growth of the weather observation infrastructure. General Circulation Models (GCM) simulate the behaviour of the climate system by dividing earth into three-dimensional grids and using supercomputers to solve mathematical equations which represent exchanges of matter and energy between the grid points. Based on GCMs, climate scientists increasingly represented the Earth's climate as an integrated global system, to be known through new geometrics like the global average temperature (Shackley; Wynne, 1996; Lahsen, 2005; Edwards, 2010; Hulme, 2010).

In the 1980s, climate modelling technology moved in the direction of increasing the complexity of numerical representations of the Earth system. Modelers recognized that the transfer of energy between oceans and atmosphere plays an extremely significant role in both weather and climate. For this reason, they started to couple models of the general ocean circulation with the global atmospheric models, creating the first versions of "Earth System Models". Gradually, modelers began to couple other climate-related systems to the ocean-atmosphere, such as the land surface, the cryosphere (glaciers, sea ice, and snow cover), the hydrosphere (lakes, rivers, evaporation, and rainfall), and vegetation. Today, Earth System Models are the most complex instruments for long term climate projection, and 
they have become central tools to produce future projections of climate change impacts (Harper, 2008; Weart, 2010; Edwards, 2010).

Since its beginning in 1988, the IPCC derived much of its understanding of climate from the work of climate modelers. To serve the IPCC assessment process modelers initiated a number of exercises in model evaluation, the most important of these exercises being model intercomparison. Model intercomparison exercises require each modelling group to run its model using a specific set of parameters (monthly average sea surface temperature, sea ice distribution etc.) to provide specific output variables in a standard format, thus creating a basis for intercomparing model performance and diagnosing the sources of differences in model behaviour (Meelh et al., 2000). Today, the most important model intercomparison project linked to the IPCC is the Coupled Model Intercomparison Project (CMIP), organized under the umbrella of the World Climate Research Program (WCRP) ${ }^{5}$. The objective of the CMIP is to produce model experiments to simulate "past, present and future climate changes arising from natural, unforced variability or in response to changes in radiative forcing in a multi-model context ${ }^{\prime \prime}$. This understanding includes assessments of model performance during the historical period and quantifications of the causes of the spread in future projections. Keeping up with the "state of the art" of earth system modelling requires continuous investment in an infrastructure of advanced supercomputers and human capacity.

Only a few climate modelling groups have the necessary infrastructures to execute global climate modelling experiments and participate in the CMIP. As Edwards (2010, p.172) points out, "just 33 groups submitted GCMs for the Atmospheric Model Intercomparison Project" (AMIP) ${ }^{7}$ in the

\footnotetext{
${ }^{5}$ The WCRP was established in 1980 under the joint sponsorship of the International Council for Science (ICSU) and the World Meteorological Organization (WMO). In 1993 the Intergovernmental Oceanographic Commission (IOC) of UNESCO also became a sponsor. The main objectives of WCRP, defined at its inception and still valid today, are to determine the predictability of climate the effects of human activities on climate. See: https://www. wcrp-climate.org/wgcm-cmip.

${ }^{6}$ See the main program description in the website of CMIP: https://www.wcrp-climate.org/ wgcm-cmip.

${ }^{7}$ AMIP was the first model intercomparison project, which had less computer-intensive experiments and used atmospheric global circulation models with smaller complexity than the Earth System Models (Edwards, 2010, p. 171).
} 
1990's; a few years later, "only about 18 groups with Atmosphere-Ocean Coupled General Circulation Models [the first version of Earth System Models] submitted outputs to CMIP - reflecting the greater complexity and larger computational requirements of coupled models". Importantly, CMIP simulations came from the historical leaders in climate modelling: Europe, Japan and USA - and still did not include members from Global South. This only changed in 2013 - when Brazil and China made their contributions. On the exclusivity of CMIP, Edwards points out:

In the political arena, this fact contributes to a widespread perception that the issue of climate change "belongs" to the developed countries, not only because they are the initial (and still principal) sources of fossil fuel emissions but also because they are the "owners" of knowledge about the problem (Edwards, 2010, p.171).

The elite world of global climate simulation persists because the entry barriers to the 'club' are very high. To participate, climate modelling groups need to have the most advanced supercomputing infrastructures ${ }^{8}$, expert teams in modelling and large financial support to maintain these highly expensive systems. In addition, the modelling teams need to be prepared to develop climate models and improve them according to the standards set by CMIP's leading members. These kinds of infrastructural conditions carry a high financial cost to countries in the Global South.

Nevertheless, in the last phase of CMIP9 ${ }^{9}$ the Fifth IPCC Report - for the first time a Latin American country introduced global climate modelling outputs into the CMIP. These outputs were produced by Brazilian modelers of the National Institute for Space Research (INPE) involved in the national project of developing the Brazilian Earth System Model (BESM). As we can see in the following table, Brazil figures between the other selected modelling groups as a participant in CMIP Phase 5.

\footnotetext{
${ }^{8}$ In 2015, the ten most powerful supercomputers in the world were in China (1st place), United States (2nd, 3rd, 5th, 6th and 10th place), Japan (4th place), Switzerland (7th place), Germany 8th place) and Saudi Arabia (9th place). But in several positions on the list, there is a massive presence of the United States with 193 supercomputers installed in the country. Source: http://www.top500.org/lists/2015/11/.

${ }^{9}$ The CMIP performed five phases of modelling experiments related to the production of the five IPCC reports, respectively, in the years 1990, 1995, 2001, 2007, 2013. See: http:// cmip-pcmdi.Inl.gov/cmip5/index.html.
} 
Table 1: Countries, Climate Centres and Climate Models participants of CMIP5

\begin{tabular}{|c|c|c|}
\hline Countries & Climate Centers & Climate Models \\
\hline Australia & CSIRO-BOM & ACCESS 1.0, 1.3 \\
\hline China & $\mathrm{BCC}$ & BCC-CSM 1.1, 1.1 (m) \\
\hline China & GCESS & BNU-ESM \\
\hline Canada & СССМА & CanESM2,CanCM4, CanAM4 \\
\hline USA & DOE-NSF-NCAR & $\begin{array}{l}\text { CCSM4, CESM1 (BGC), (CAM5), (CAM5.1, FV2), } \\
\text { (FASTCHEM), (WACCM) }\end{array}$ \\
\hline USA & RSMAS & CCSM4(RSMAS) \\
\hline Italy & CMCC & CMCC, CESM, CM, CMS \\
\hline France & CNRM/CERFACS & CNRM-CM\% \\
\hline Australia & CSIRO/QCCCE & CSIRO-Mk3.6.0 \\
\hline Europe & EC-EARTH & EC-EARTH \\
\hline China & LASG-IAP \& LASG-CESS & FGOALS - g2, s2, gl \\
\hline China & $\mathrm{FIO}$ & FIO-ESM \\
\hline USA & NASA/GMAO & GEOS-5 \\
\hline USA & NOAA/GFDL & $\begin{array}{l}\text { GFDL - HIRAM-C360, HIRAM-C180, CM2.1, CM3, } \\
\text { ESM2G, ESM2M }\end{array}$ \\
\hline USA & NASA/GISS & GISS E2-H, E2-H-CC, E2-R, E2-R-CC, E2CS-H, E2CS-R \\
\hline UK & $\mathrm{MOHC}$ & Had-CM3, CM3Q, GEM2-ES, GEM2-A, GEM2-CC \\
\hline Korea/UK & $\mathrm{NMR} / \mathrm{KMA}$ & HadGEM2-AO \\
\hline Russia & INM & INM-CM4 \\
\hline France & IPSL & IPSL - CM5A-LR, CM5A-MR, CM5B-LR \\
\hline Japan & MIROC & MIROC - 5,3 m, 4 h, ESM, ESM-CHEM \\
\hline Germany & MPI-M & MPI-ESM - HR, LR, P, ESM-P \\
\hline Japan & MRI & MRI - AGCM3, 2H, AGCM3.2S, CGCM3, ESM1 \\
\hline Norway & NCC & NorESM1-M, NorESM-ME \\
\hline USA & NCEP & CFSv2-2011 \\
\hline Japan & NICAM & NICAM-09 \\
\hline Brazil & INPE & BESM OA2.3 \\
\hline
\end{tabular}

Source: Taylor, 2012. 
As table 1 makes clear, most of CIMP5's participating climatological centres are North American, European or wealthy Asian nations as Japan and South Korea. Brazil and China are exceptions from the 'South'. It should be noted (in the third column) that the United States participated with output from twenty-two models, which denotes a high climate modelling capability and a larger volume of simulations included in the CMIP5 database compared to other countries ${ }^{10}$.

It is important noting that the scientific questions and the criteria adopted by the CMIP are defined by its organizing committee composed of seven members from North American and European meteorological centres, the USA, France, Germany and the UK (Eyring et al., 2016). Activities for future CMIPs have been reconfigured, aiming to conduct experiments at even more advanced stages of global modelling (Eyring et al., 2016). The required advances make the relationship between climatological centres in this project increasingly hierarchical as the new advances are produced by the most advanced modelling centres in the North, while Southern Hemisphere countries remain mostly absent from these decision-making structures.

Global climate modelling practice occurs in specific sites of climate knowledge production. The "global" character of these international projects masks the unequal division of labour between North and South in the international climate science system. As a Brazilian climate modeler pointed out,

the developed climate centres develop the scientific guidelines, questions and requirements for the CMIP project and produce the most important results and countries with less capacity as Brazil participate with a few simulations that are included in the final report (quoted in Miguel, 2017, p. 180)

In that sense, global climate modelling practice reflects the severe imbalance between developed and developing countries in the generation of scientific knowledge in environmental science (Karlsson; Srebotnjak;

\footnotetext{
${ }^{10}$ Although countries like China and France have acquired powerful supercomputers and applied this computing power to climatology, the USA still leads the field, having the largest number of researchers, the most powerful calculation capabilities, and the best research centers.
} 
Gonzales, 2007). However, what does this "imbalance" mean to the political stances of Global South nations, and how do scientific groups react to IPCC asymmetries? To explore these questions, we now describe the "infrastructural geopolitics" of the Brazilian Earth system modelling project.

\section{The Brazilian way to the IPCC global modelling club}

To understand how Brazilian climate scientists from the scientific "periphery" were able to integrate the highest level of IPCC modelling experiments with BESM, we need to consider the local conditions and historical evolution of climate modelling science in Brazil. Climate modelling started in Brazil in 1994 with the creation of the Centre for Weather Forecasting and Climate Studies (CPTEC) in the Brazilian National Institute for Space Research (INPE). To start the numerical predictions in CPTEC, the local government first imported a global climate model from a North American climate centre, "COLA" (The Centre for Ocean-Land-Atmosphere Studies). Gradually the CPTEC team improved on the model with new components that represented the climate system that governs the weather in South America. Making these improvements was not easy: lack of financial resources and the absence of modelling experts were some of the problems faced by Brazilians at the time. But despite all these difficulties, the team managed to start operational numerical weather prediction in Brazil (Miguel; Escada; Monteiro, 2016).

Significant transformations occurred in climate science in general and in the climate modelling field in Brazil after the year 2007. The national economic and political situation and the publication of the IPCC AR4 in 2007 pushed for a process of institutionalization of climate change policy, which in turn restructured climate science networks in Brazil'11. The Lula presidency (2003-2011) was a particularly favourable political and economic moment for Brazilian science, with rising investments and

\footnotetext{
"After the IPCC/AR4 - which declared that the "warming of the climate system is unequivocal" (IPCC, 2007, p. 30) - the Brazilian government and funding bodies responded with a fast process of institutionalization of climate change policy and by forming climate change scientific networks like "Rede Clima" (Brazilian Climate Change Research Network), "INCT - Mudanças Climáticas" (National Institute for Climate Change Science) and "Programa FAPESP Mudanças Climáticas" (The Program of São Paulo Science Foundation for Climate Change) (Miguel, Escada and Monteiro, 2017).
} 
expanding infrastructure in science and technology (Petherick, 2010). There was widespread optimism with what was considered a long-awaited "take off"12, with expectations that the country would become the fifth-largest economy in the world and would occupy a more relevant role in the world stage. Investment in science and technology grew in strategic areas like oil and energy, but also in sciences for diplomatic and environmental issues like remote sensing in Amazonia - to reduce the rates of Amazon deforestation - and climate change studies - to inform the government and the Brazilian delegation to plan the participation of Brazil in the United Nation Framework Convention on Climate Change (UNFCCC) negotiations in Copenhagen, 2009 - (Monteiro, 2014, 2015; Monteiro and Rajão, 2017; Miguel, 2017). The political momentum created the opportunity for climate modelers of CPTEC to launch the scientific project of an Earth System Model.

The Brazilian Earth System Model project started in 2008, when the Centre for Earth System Science (CCST) associated to CPTEC, at INPE, was created. The project was coordinated by some of the leading climate science researchers in Brazil - including some Brazilian members of IPCC. The project was supported by the Ministry of Science, Technology and Innovation (MCTI) and the main national science funding agencies like São Paulo Research Foundation (FAPESP), Brazilian Innovation Agency (FINEP) and National Council for Scientific and Technological Development (CNPq). The volume of funding - compared to other projects supported by the same agencies - represented the largest amount of public investment ever awarded to a single project in climate change research in Brazil (Miguel, 2017).

After 2007, the interest in climate change simulations grew between decision makers in the Ministries of Foreign Affairs, Science and Technology, and Environment. Scientific information about climate change impacts was considered the most important scientific resource for advancing the goals set by the national policy on climate change and for formulating the national plan for adaptation to climate change. In the National Policy on Climate Change it is stated that:

When we consider the issue of climate change in Brazil, we face the problem of the lack of reliable scenarios of the possible future of the climate in the

${ }^{12}$ See: http://www.economist.com/node/14845197. 
country, which has great proportions [...]. In order to elaborate these studies, however, there is a need for the development of long-term climate change models with appropriate spatial resolution for regional analysis, which will create the conditions for the development of scenarios of possible future climate change with different concentrations of carbon dioxide in the atmosphere and to analyse the impacts of global climate change in Brazil. [...] With these results, the country will be better able to identify the most vulnerable regions and sectors with a higher degree of reliability than offered by the IPCC's global models, and to develop specific adaptation projects with the appropriate scientific basis, enabling a more rational allocation of public resources. (Brasil, 2007, p. 84-87, translation by the author)

This notion that by knowing possible climate change scenarios the country would be better prepared to identify more vulnerable regions was widespread among policy makers. Trust in the science of modelling justified the large investments made in BESM. In this regard, one of the statements of the secretary of the Strategic Affairs Secretariat of the Presidency (SAE) was illustrative: "with the BESM project, INPE's modelers are putting a 'magnifying glass' over the Brazilian territory to identify climate change impacts"13 (quoted in Miguel, 2017, p.146).

This "practical instrumental" value (Elzinga, 1993) of climate modelling that attracts decision makers was used by BESM modelers as a rhetorical resource that legitimized modelling practice. The modelers also affirmed that "we need to represent aspects of the regional nature that influence climate dynamics in South America so we will produce more reliable climate change scenarios for Brazil", and "with the BESM model, we can anticipate extreme weather events which mainly affect the poorest populations" (Miguel, 2017, p.145). This rhetoric of scientific predictive power was used powerfully in the public communication of the BESM project to legitimize the huge investments in modelling technology.

Furthermore, the actors involved in the BESM defended the project as an emblem of national scientific capacity with a "symbolic instrumental value" (Elzinga, 1993): a symbol of national scientific power. Echoing Dalby's (2013) comments about the centrality of climate geometrics to

\footnotetext{
${ }^{13}$ This is declared by the secretary of the Strategic Affairs Secretariat of the Presidency (SAE) in a public interview in 2014 when he announced the investment of two million Reais in the BESM model (Miguel, 2017, p.150).
} 
climate geopolitics, it was stated that "Brazil needs to have autonomy in the production of climate future simulations to advise with sovereignty the decision making in climate change issues" (BESM - Coordinator) (Miguel, 2017, p. 181). As other case studies have shown (Lahsen, 2002; Mahony, 2014), the pragmatic role of climate modelling is often associated with the discursive construction of the nation-state's capability to manage its own issues related to the impacts of climate change within its territorial domain (see also Whitehead et al., 2007). Climate modelling is considered a strategic resource which sovereign countries should not fail to develop through their own, endogenous scientific capabilities. Indeed, the shaping of BESM was closely related to an articulation of Brazil exercising its own epistemic (and thus political) sovereignty on climate change issues.

The scientific community gathered in the BESM project was able to associate the objectives of the project with the nationalist appeal of Lula's government. They named the project "Brazilian Earth System Model", with the evident intention to emphasize that this type of technology was being developed autonomously by a team of national researchers. Just as then president Lula frequently used the phrase "never before in the history of our country"14 to highlight the exceptional character of his government, BESM modelers used the slogan "Brazilian Climate Model, for the first time at the IPCC" as an emblem of Brazil's then growing scientific power. The alignment of these discourses reinforced the legitimacy of the BESM group and enabled it to acquire more public funding and become the central scientific project for climate change in Brazil in that period.

In 2010, the Brazilian government acquired one of the most powerful supercomputers available at the time with the purpose of improving weather forecasting and climate change simulations. This expensive infrastructure was installed at the CPTEC/INPE and was celebrated as a milestone in Brazilian climate science. Named "Tupã" - after a native South American god of thunder - the supercomputer Cray XT6 boosted new advances in climate and Earth system modelling. With this new infrastructure, the BESM

\footnotetext{
${ }^{14}$ President Lula was known for his emblematic phrases that emphasized the exceptional character of his government. "Never before in the history of our country" during the former president's government was used in many instances as an emblem of sovereignty and national development.
} 
group started the experiments for the CMIP5. The new supercomputer infrastructure and the campaign for global climate modelling in Brazil were internationally recognized as a national scientific achievement. In an emblematic Nature article, it was declared that with the supercomputer Tupã, "Brazil's Climate Modelers are set to go global" (Tollefson, 2010). The author stated that "the new supercomputer could help to earn Brazil a place in the small club of nations that contributes global climate modelling expertise to the IPCC" (Tollefson, 2010, p.01)

However, the experiments with the BESM model did not materialize easily. Despite the availability of the supercomputer infrastructure, the group did not have enough climate modelling experts to conduct the CMIP experiments. It was necessary to organize international workshops to attract young researchers from other countries (India, South Africa and China) to participate in the project (Miguel, 2017). Also, to complete the modelling team, Brazilian researchers who were conducting their professional careers in the USA were "repatriated". As the BESM's coordinators stated: "one thing that was very clear is that without specialized manpower in climate modelling, there would be no Brazilian modelling at CMIP5" (Miguel, 2017, p. 181).

Expectations surrounding BESM - that it would contribute to the IPCC - put pressure on the climate modelling group. Millions invested in the computer program needed to be justified by results. However, one important condition for participating in the CMIP5 was that the results of the modelling experiments needed to be published in high-impact international scientific journals. Therefore, the group of Brazilian modelers directed all their efforts to conduct model simulations encompassing the time period from 1960 to 2105 - following the phase 5 of the CMIP protocol ${ }^{15}$. These experiments occurred just in time to include the outputs in the CMIP5 basis. The results were submitted and subsequently published in the Journal of Climate of the American Meteorological Society (Nobre et al., 2013) - a journal coordinated by some of the leading North American scientists of CMIP - allowing Brazil to be officially included in the IPCC5 modelling basis.

${ }^{15}$ See: http://cmip-pcmdi.Ilnl.gov/cmip5/ 
Once the results of BESM were admitted to the CMIP5, this milestone was celebrated as a major achievement of national science in some of the main vehicles of the Brazilian media. Major national newspapers reported in 2013 that for the first time Brazil "will have a climate model at the United Nations", that such a model "is the first to have IPCC endorsement in Latin America" to "simulate the climate around the world" (Escobar, 2015). This "national pride" expressed a desire to see Brazil strengthen its national expertise in the climate change area. The global climate model therefore became an emblem of scientific capacity. In the next section, we discuss the geopolitical meaning of this kind of scientific achievement considering the North-South divide of IPCC composition.

\section{The infrastructural geopolitics of climate knowledge}

Regarding climate knowledge infrastructures as only "machines to build" implies a downplaying of the importance of social, institutional, cultural, political and other non-technical problems that their builders always face. And when we talk about the global knowledge infrastructures like those that coalesce in the IPCC, the asymmetries between scientific groups and their particular intentions in the IPCC are obliterated under terms like "international scientific cooperation" or "global scientific effort"16.

Nevertheless, the North-South division of labour in the IPCC is significant, framing and shaping climate change knowledge. Despite increasing attention paid by the IPCC's governing bureau to the participation of authors and reviewers from developing countries in the assessment process, the percentage of both authors and reviewers from Global South nations has remained small in all IPCC reports (See figure 1).

${ }^{16}$ The terms are often applied by the media, by scientists and appear in the IPCC's reports to enforce the global character of the panel's climate knowledge. 
Figure 1: Geography of IPCC expertise.

Geography of IPCC contributors*

Geography of IPCC contributors involved in each Assessment Report

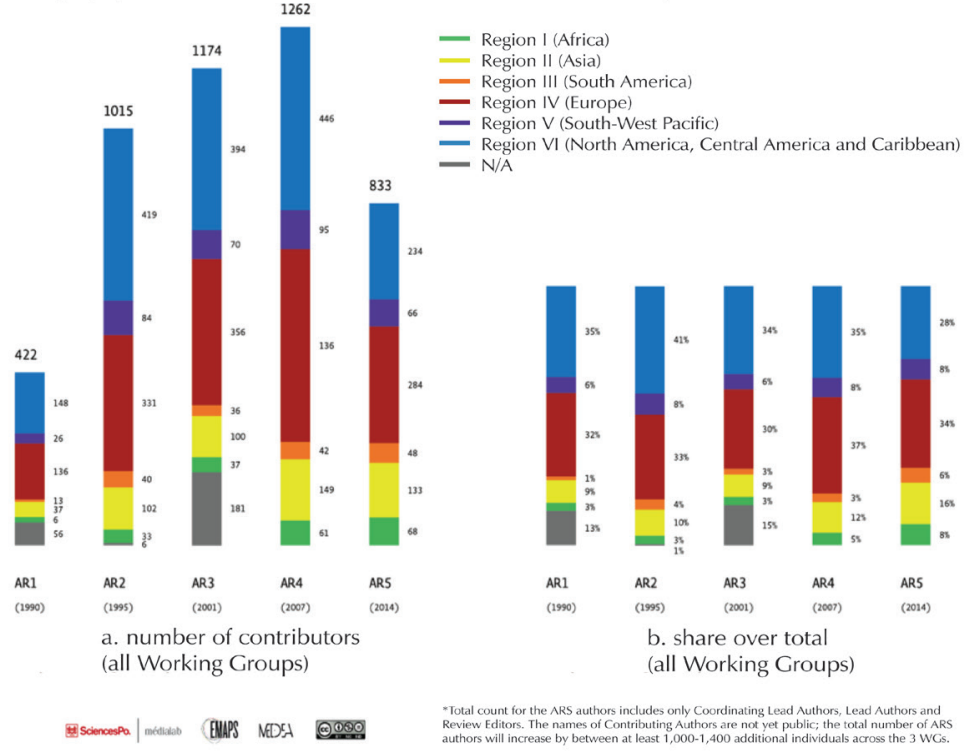

Source: SciencePO MediaLab (2016) ${ }^{17}$

The consequences of a geographical bias in IPCC expertise has been discussed extensively as a problem affecting the legitimacy of the assessment reports (Kandlikar; Sagar, 1999; Lahsen, 2004; Wynne, 1996; 2010; Hulme; Mahony, 2010; Mahony, 2014). Lahsen (2004) pointed out that Brazilian leaders involved with international climate negotiations and members of the scientific community were concerned to build national expertise in climate research in order to defend the 'national interest'.

The BESM project reflects this concern about the imbalances in the production of IPCC knowledge. Brazilian scientist and IPCC vice-president Thelma Krug illustrated this concern when she declared that less developed

${ }^{17}$ See: http://www.medialab.sciences-po.fr/ipcc/ . 
nations such as Brazil "cannot fail to have a supercomputer and climate modelling infrastructure" (Angelo, 2015, p. 2, our translation). In her view it is not enough for developing countries to have IPCC chair nominations; just as important is to have the capacity to produce physical and natural scientific knowledge of climate change. Krug said that she discussed with members of the IPCC presidency about inequalities and they argued that "developing countries do not have the installed capacity to work with global and regional climate models. We cannot simply put these people [researchers from these countries] just to make numbers and geographical balance in the IPCC" (Angelo, 2015, s/p). Indeed, including researchers with different nationalities does not necessarily translate into inequality reduction in the IPCC's production of climate knowledge (Lahsen, 2007).

The difficulties encountered in producing climate-environmental knowledge in emerging countries such as the BRICS group (Brazil, Russia, India, China and South Africa) led these countries to agree on scientific cooperation in environmental research. In 2014, the BRICS summit was held in Brazil. On that occasion, the coordinator of BESM, the Brazilian climatologist Carlos Nobre - at the time, also secretary of the Ministry of Science, Technology and Innovation - declared in the workshop on scientific cooperation that the generation of researchers of which he is part "was formed in a time of science production which everything passed through the USA and Europe"18. Nobre emphasized that "we, from developing countries, always looked to the North for scientific cooperation," but now we are aware that "the world is not only composed of one hemisphere and the BRICS nations clearly show other arrangements, which are essential for the sustainable development of the planet as a whole"19. The workshop ended with the formulation and approval of a document establishing BRICS cooperation in the areas of oceanographic research, climate modelling, and prevention of natural disasters. It is therefore a process of scientific cooperation that seeks to produce new geopolitical arrangements for scientific exchange, apart from those through which such scientists may have historically cooperated with the North. In these new geopolitical-scientific

\footnotetext{
${ }^{18}$ See:http://www.mct.gov.br/index.php/content/view/354425/Brics_trocam_ideias_em_ mudancas_climaticas_e_prevencao_de_desastres.html.

${ }^{19}$ Idem note 18.
} 
alignments that the BRICS countries intended to construct, some specific knowledge areas were selected to achieve such objectives, including climate modelling, which figured prominently as a strategic field.

One month before the BRICS workshop in Brazil, the BESM model was presented in China to join efforts among modelling teams from the South. Like Brazil, China, in the international arena, participates in the negotiations on climate change with a strong geo-strategic initiative, seeking to strengthen cooperation with other countries for financing, technology transfer and capacity-building for adaptation (Moreira; Ribeiro, 2016). Climate modelling appears in these relations as a strategic scientific field, one of the areas of scientific cooperation on which countries in the South should focus if they want to acquire greater instrumental and symbolic power in global environmental arenas.

Similarly, the recent history of climate science in India is expressive of the geopolitical power of climate modelling in the context of a North-South divide. The coproduction of climate modelling and climate-political order in India demonstrates the "agonistic coexistence" of different strategies of reproducing the nation state in the putative global space of international climate science and politics. The development of climate modelling science has likewise been framed as a matter of national sovereignty, without which it is impossible to enter the political fray on an equal footing with northern countries. However, beneath the rhetoric of sovereignty lies something deeper - around the time of the Copenhagen negotiations, the symbolic power of climate models was utilized by the Indian environment minister as significantly in the domestic as in the international sphere - new Indian climate modelling facilitated the Minister's moves to bring India closer to the US in terms of advocating voluntarist and market-based mitigation mechanisms. As some critics saw Indian territorial sovereignty being ceded, the discursive emphasis on epistemic sovereignty was an important political move.

Our analysis of the BESM case likewise illustrates that global climate knowledge production is a process that should be understood as composing an "infrastructural geopolitics", involving unequal relations of power that permeate the Global North/South divide. These relationships are conditioned 
by access to infrastructure for the production of climate knowledge, and thus the arenas for politics go beyond those usually analysed as such (i.e. the UN and global political fora), including scientific institutions and how they factor into international relations. The uneven geographies of global climate modelling, and the striving for scientific autonomy among both policymakers and BESM's modelling team, indicate the existence of a process that forces us to rethink our historical understanding of the infrastructural globalism of the climate sciences (Edwards, 2010).

Edwards (2010) points out that the climate sciences have made an unprecedented effort in international scientific coordination to share information and develop a comprehensive infrastructure of global climate knowledge. However, his analysis focuses on the development of climatological infrastructures mainly in the USA and in Europe. The Brazilian case of BESM brings to light something different: the condition of inequality in the production and national control of these infrastructures, and the geopolitical effects of this inequality. With climate geopolitics increasingly organized around knowledge emerging from the observations and simulations of the climate science community, understanding the instrumental and symbolic power of these epistemic constructs is crucial. Building knowledge infrastructures is an increasingly prominent means of engaging in geopolitics. ${ }^{\mathbf{2 0}}$

The "globalist" process of climate science, which sought to cross political boundaries and establish a global epistemic community, has nuances that reveal different agendas and conflicts between epistemic groups in developed and developing countries (Lahsen, 2004; Miller, 2004; Jankovic, 2004; Mahony, 2014). The case of Brazilian climate modelling exemplifies the infrastructural geopolitics of climate knowledge, managed by a scientific group from an emerging country that traditionally took positions in the climate negotiations as a leader of developing countries with a strong "sovereignty" discourse (Viola, 2002; Viola; Franchini, 2013). The BESM shows the concern of a Global South nation to build national expertise in

${ }^{20}$ With recent developments in the US, we might also note how destroying or protecting knowledge infrastructures has also become a mode of geopolitics. See Walker et al., 2018. 
climate research in order to defend the "national interest"; to develop a political machine with which global power relations could be reshaped.

\section{Conclusions}

The history of climate science and the IPCC demonstrates that new constructions of natural and social order on global scales are highly interdependent (Miller, 2004). The IPCC's role in this co-production has depended on its ability to construct itself as a legitimate institution of global cooperation.

In this article, we have argued that some Brazilian climate modelers, as developing country researchers, express a common Global South concern over the privilege of a form of climate science that is based nearly exclusively on the work of laboratories and modelling centres in the Global North. When analysing the BESM group, we perceive that national investments in global modelling aim to achieve a condition of scientific sovereignty that is tightly coupled to a notion of political sovereignty of the nation-state in the international climate change regime. In this way, scientific knowledge and its infrastructures are deeply imbricated in the geopolitics of climate change. These are processes that we have called the infrastructural geopolitics of climate knowledge.

This analysis, we realise, is based on a project which was linked to a particular political project, very different from the one now in power in Brazil. As Bolsonaro's agenda for environmental policy, climate change policy and science and technology unfold and become clearer, the previous initiatives to achieve scientific autonomy in climate science linked to increasing spending in large-scale modelling infrastructures seems to be a thing of the past. Current policies seem to be aimed at changing Brazil's discourse on environmental protection and deforestation, shifting from a decades-long effort to build a leading position on global environmental governance to a new stance that critiques environmental protection as leftist rhetoric and values economic growth through farming and cattle, at the expense of increasing deforestation rates. Further research would be needed in order to fully assess how these shifts will change Brazil's current geopolitical position in global climate governance mechanisms. 
The infrastructural globalism of climate science can be much better understood if we take into consideration the asymmetries and conservative aspects of international scientific networks and how they are linked to geopolitical questions. In this sense, it is necessary to discuss in a more direct way the science and technology policies that are implicit in the IPCC, putting in focus the knowledge that is privileged in its Working Groups and who produces them. In a period of apparent fragmentation of the global climate regime, and of the renewed assertion of nation-state territoriality in relation 'global' issues, it is more important than ever to understand how science and politics, and epistemic and political sovereignty, are connected and deployed in the conduct of climate geopolitics. Such an undertaking can help us interrogate the processes by which global climate change issues are defined, and to examine how they serve to channel power in certain directions.

\section{Acknowledgements}

We would like to thank Tiago Ribeiro, Luís Reyes-Galindo and Sandra Harding, who contributed to the revision of this article.

Jean Carlos Hochsprung Miguel holds a PhD in Scientific and Technological Policy from the State University of Campinas (UNICAMP), Sao Paulo, Brazil.

$\emptyset^{\circ}$ jean.dpct@gmail.com

Martin Mahony holds a PhD in Geography and is lecturer in Human Geography at the School of Environmental Sciences, University of East Anglia, Norfolk, United Kingdom.

ڤm.mahony@uea.ac.uk

Marko Synésio Alves Monteiro holds a PhD in Social Sciences and is associate professor at the Department of Science and Technological Policy in the State University of Campinas (UNICAMP), São Paulo, Brazil.

ఏ carambol@unicamp.br 


\section{References}

1. ABESSA, Denis; FAMÁ, Ana; BURUAEM, Lucas. The systematic dismantling of Brazilian environmental laws risks losses on all fronts. Nature Ecology \& Evolution, v. 3, n. 4, p. 510-511, 2019. doi: 10.1038/s41559-019-0855-9

2. ANDRY, Barry. Material politics: disputes along the pipeline. Hoboken: John Wiley and Sons, 2013.

3. ANGELO, Claudio. Brazil's government freezes nearly half of its science spending. Nature, n. 568, p. 155-156, 2019. doi: 10.1038/d41586-019-01079-9

4. ANGELO, Claudio. País não pode abrir mão de supercomputador. Observatório do Clima [online]. URL: http://www.observatoriodoclima.eco.br/pais-nao-podeabrir-mao- de-supercomputador/.

5. BRASIL - Governo Federal. Plano Nacional sobre Mudanças do Clima - PNMC - Brasil. Decreto no 6.263, de 21 de novembro de 2007. Comitê Interministerial sobre Mudanças do Clima. Brasília: Ministério do Meio Ambiente, 2008. URL: http://www.mma.gov.br/estruturas/smcq_climaticas/_arquivos/plano_nacional_ mudanca_clima.pdf.

6. CHARMAZ, Kathy. Constructing grounded theory: a practical guide through qualitative analysis. London: SAGE Publications, 2006.

7. DALBY, Simon. The geopolitics of climate change. Political Geography, v. 37, p. 38-47, Nov. 2013. doi: 10.1016/j.polgeo.2013.09.004

8. DEMERITT, David. The construction of global warming and the politics of science. Annals of the Association of American Geographers, v. 91, n. 2, p. 301-337, June. 2001. URL: https://www.jstor.org/stable/3651262

9. DUARTE, Tiago. Mecanismos de Homogenização da Atividade Científica: O caso da ciência de mudanças climáticas. Sociedade e Estado, v. 31, n. 3, p. 821843, 2016. doi: 10.1590/s0102-69922016.00030012

10. EDWARDS, Paul. A vast machine: computer models, climate data, and the politics of global warming. Massachusetts: The MIT Press, 2010.

11. EDWARDS, P. Meteorology as Infrastructural Globalism. The History of Science, Osiris, v. 21, n. 1, p. 229-250, 2006. doi: 10.1086/507143

12. ELDEN, Stuart. Secure the volume: vertical geopolitics and the depth of power. Political Geography, v. 34, p. 35-51, 2013. doi: 10.1016/j.polgeo.2012.12.009

13. ELZINGA, Aant. Science as the continuation of politics by other means. In: BRANTE, Thomas; FULLER, Steve; LYNCH, William. (Eds.) Controversial science: from content to contention. Albany: State University of New York Press, 1993. p.127-152.

14. ESCOBAR, Herton. Brasil prepara seu 1o modelo climático para o IPCC. Portal de Notícias Estadão Ciência. URL: http://ciencia.estadao.com.br/blogs/ herton-escobar/brasil-prepara-seu-1o-modelo-climatico-para-o-ipcc/ 
15. EYRING, Veronica et al. Overview of the Coupled Model Intercomparison Project Phase 6 (CMIP6) experimental design and organization. Geoscientific Model Development Discussion, v. 9, p. 1937-1958, 2016. doi: 10.5194/gmd9-1937-2016

16. FLEMING, James R. Inventing the atmospheric science: Bjerknes, Rossby, Wexler, and the foundations of modern meteorology. Cambridge: MIT Press, 2016.

17. HARDING, Sandra. Objectivity and diversity: another logic scientific research. Chicago e London: The University of Chicago Press, 2015.

18. HARPER, C. Kristine. Weather by the numbers. The genesis of modern meteorology. Massachusetts: The MIT Press, 2008.

19. HULME, Mike. How Climate Models Gain and Exercise Authority. In: HASTRUP, Kirsten; SKRYDSTRUP, Martin (Eds.) The social life of climate change models: antecipating nature. New York: Routledge, 2013. p. 30-44.

20. HULME, Mike; MAHONY, Martin. Climate change: what do we know about the IPCC? Progress in Physical Geography, v. 34, n. 5, p. 705-718, 2010. doi: $10.1177 / 0309133310373719$

21. IPCC. Intergovernmental Panel on Climate Change. Principles Governing IPCC Work, 2013. Available at: https://www.ipcc.ch/pdf/ipcc-principles/ipcc-principles. pdf.

22. JACKSON, Steven J.; EDWARDS, Paul N.; BOWKER, Geoffrey C.; KNOBEL, Cory P. Understanding Infrastructures: History, Heuristics, and Cyberinfrastrutures Policy. First Monday. Journal on the Internet, v. 12, n. 6, June 2007. URL: http:// www.firstmonday.org/ojs/index.php/fm/article/view/1904/1786.

23. JANKOVIC, Vladimir. Science migrations: mesoscale weather prediction from Belgrade to Washington, 1970-2000. Social Studies of Science, v. 34, n. 1, p.4575, 2004. doi: 10.1177/0306312704040490

24. JENSEN, Casper B.; WINTHEREIK, Britt R. Monitoring movements in development aid: recursive partnerships and infrastructures. Cambridge: The MIT Press, 2013.

25. JOSHI, Shangrila. Understanding India's representation of North-South climate politics. Global Environmental Change, v. 13, n. 2, p.128-147, 2013. doi: 10.1162/GLEP_a_00170

26. KANDLIKAR, Milind; SAGAR, Ambuj. Climate change research and analysis in India: an integrated assessment of a South-North divide. Global Environmental Change, v. 9, n. 2, p.119-138, 1999. doi: 10.1016/S0959-3780(98)00033-8

27. KARLSSON, Sylvia; SREBOTNJAK, Tanja; GONZALES, Patricia. Understanding the North-South knowledge divide and its implications for policy: a quantitative analysis of the generation of scientific knowledge in the environmental sciences. Environmental Science and Policy, v. 10, n. 7-8, p. 668-684, 2007. doi: 10.1016/j.envsci.2007.04.001 
28. KREIMER, Pablo. Emergencia y desarrollo de campos científicos en la periferia: Argentina, segunda mitad del Siglo XX. Buenos Aires: CLACSO, 2016.

29. LAHSEN,Myanna. Brazilian climate epistemerss' multiple epistemes: exploration of shared meaning, diverse identities and geopolitics in global change science. Discussion Paper, 2002-01. Cambridge, MA: Environment and Natural Resources Program, Belfer Center, Kennedy School of Government, Harvard University, 2002.

30. LAHSEN, Myanna. Transnational locals: Brazilian experiences of the climate regime. In: JASANOFF, Sheila; MARTELLO, Marybeth (Eds.) Earthly politics: local and global in environmental governance. Massachusetts: The MIT Press, 2004. p. 151-172.

31. LAHSEN, Myanna. Seductive simulations? Uncertainty distribution around climate models. Social Studies of Science, v. 35, n. 6, p. 895-922, 2005. URL: www.jstor.org/stable/25046680

32. LAHSEN, Myanna. Trust through participation? Problems of knowledge in climate decision making. In: PETTENGER, Mary (Ed.) The social construction of climate change. Hampshire: Ashgate, 2007. p. 173-196.

33. MAC LEOD, Roy. On visiting the 'moving metropolis': reflections on the architecture of imperial science. Historical Records of Australian Science, v. 5, n. 3, p.1-16, 1982. doi: 10.1071/HR9820530001

34. MAHONY, Martin. The predictive state: science, territory and the future of the Indian climate. Social Studies of Science, v. 44, n. 1, p. 109-133, 2014. doi: 10.1177/0306312713501407

35. MAHONY, Martin; HULME, Mike. Model migration: mobility and boundary crossing in regional climate prediction. Transaction of the Institute of British Geographers, v. 37, n. 2, p. 197-211, 2012. doi: 10.1111/j.14755661.2011.00473.x

36. MEEHL, Gerald; BOER, George; COVEY, Curt; LATIF, Mojib; STOUFFER, Ronald. The Coupled Model Intercomparison Project (CMIP). Bulletin of American Meteorological Society, v. 81, n. 2, p. 313-318, 2000.

37. MIGUEL, Jean C. H. Políticas e infraestruturas das ciências atmosféricas: um estudo social da modelagem climática no INPE. Tese [Doutorado em Política Científica e Tecnológica]. Instituto de Geociências, Universidade Estadual de Campinas, 2017.

38. MIGUEL, Jean C. H.; ESCADA, Paulo; MONTEIRO, Marko. Meteorologia no Brasil: a coprodução do conhecimento e das políticas científicas na criação do CPTEC. Revista Brasileira de História da Ciência, v. 9, n. 1, p. 36-60, 2016.

39. MILLER, Clark. Climate science and the making of a global political order. In: JASANOFF, Sheila (Ed.) States of knowledge: the Co-production of science and social order. London: Routledge, 2004. p. 46-66.

40. MILLER, Clark A. Scientific internationalism in American foreign policy: the case of meteorology, 1947-1958. In: MILLER, Clark A.; EDWARDs, Paul N. 
Changing the Atmosphere: expert knowledge and environmental governance. Cambridge, Massachusetts: The MIT Press, 2001. p. 168-218.

41. MILLER, Clark A.; EDWARDs, Paul N. Changing the Atmosphere: expert knowledge and environmental governance. Cambridge, Massachusetts: The MIT Press, 2001.

42. MONTEIRO, Marko S. A. Modelling Amazonian environments: some considerations on the science-policy interface in Brazil. Paper Presented at 4S-ESOCITE Joint Meeting. Buenos Aires, 2014.

43. MONTEIRO, Marko S. A. Construindo imagens e territórios: pensando a visualidade e a materialidade do sensoriamento remoto. História, Ciências, Saúde-Manguinhos, Rio de Janeiro, v. 22, n. 2, p. 577-591, 2015. doi: 10.1590/ S0104-59702015000200006

44. MONTEIRO, Marko S. A.; RAJÃO, Raoni. Scientists as citizens and knowers in the detection of deforestation in the Amazon. Social Studies of Science, v. 47, n. 4, p. 466-484, 2017. doi: 10.1177/0306312716679746

45. MOREIRA, Helena M.; RIBEIRO, Wagner C. A China na ordem ambiental internacional das mudanças climáticas. Estudos Avançados, v. 30, n. 87, p. 213234, 2016. doi: 10.1590/S0103-40142016.30870013

46. O'LEAR, Shannon; DALBY, Simon. Reframing Climate Change. Constructing Ecological Geopolitics. London: Routledge, 2015.

47. PETHERICK, Anna. High hopes for Brazilian science. Nature, n. 465, p.674675, 9 jun. 2010. doi:10.1038/465674a

48. SHACKLEY, Simon; WYNNE, Brian. Representing uncertainty in global climate change science policy: boundary-ordering devices and authority. Science, Technology \& Human Values, v. 21, n. 3, p. 275-302, 1996. URL: https://www. jstor.org/stable/689709

49. SHACKLEY, Simon. Trust in models? The mediating and transformative role of computer models in environmental discourse. In: REDCLIFT, Michael; WOODGATE, Graham (Eds). The international handbook of environmental sociology. London: Edward Elger Puplishing, 1997. pp. 237-260.

50. SHACKLEY, Simon; YOUNG, Peter; PARKINSON, Stuart; WYNNE, Brian. Uncertainty, complexity and concepts of good science in climate change modelling: are CGMs the best tools? Climate Change, v. 38, n. 2, p. 159-205, 1998. doi: 10.1023/A:100531010

51. SHACKLEY, Simon. Epistemic lifestyles in climate change modelling. In: MILLER, Clark; EDWARDS, Paul (Eds.) Changing the atmosphere: expert knowledge environmental governance. Cambridge, Massachusetts: The MIT Press, 2001. p.107-133.

52. SUDENBERG, Mikaela. Mobilizing networks. researcher roles in atmospheric science. Acta Sociologica, v. 50, n. 3, p. 271-282, 2007a. doi: 10.1177/0001699307080932 
53. SUDENBERG, Mikaela. Parameterizations as boundary objects on the climate arena. Social Studies of Science, v. 37, n. 3, p. 473-488, 2007b. doi: 10.1177/0306312706075330

54. TAYLOR, Karl. Program for Climate Model Diagnosis and Intercomparison (PCMDI), Lawrence Livermore National Laboratory. Presented to the WCRP Working Group on Coupled Modelling, Hamburg, Germany, 2012. URL: http:// www.wcrp-climate.org/wgCm/WGCM16/Taylor_CMIP5Update_WGCM16.pdf.

55. TOLLEFSON, Jeff. Brazil's climate modellers are set to go global. Nature, n. 468, p. 20, 04 nov. 2010. doi:10.1038/468020a

56. VIOLA, Eduardo. O regime internacional de mudanças climáticas. Revista Brasileira de Ciências Sociais, v. 17, n. 50, p. 25-46, 2002. doi: 10.1590/S010269092002000300003

57. VIOLA, Eduardo; FRANCHINI, Matias. Brasil na Governança Global do Clima, 2005-2012; a luta entre conservadores e reformistas. Contexto Internacional, v. 35, n. 1, p. 43-76, 2013. doi: 10.1590/S0102-85292013000100002.

58. WALKER, Dawn; NOST, Eric; LEMELIN, Aaron; LAVE, Rebecca; DILLON, Lindsey. Practicing environmental data justice: from data rescue to data together. Geo: Geography and Environment, v. 5, n. 2, p. 1-14, 2018. doi: 10.1002/geo2.61

59. WATTS, Jonathan. Brazil's new foreign minister believes climate change is a Marxist plot. The Guardian 11/08/2018. URL: https://www.theguardian. com/world/2018/nov/15/brazil-foreign-minister-ernesto-araujo-climate-changemarxist-plot.

60. WEART, Spencer. The development of general circulation models of climate. Studies in History and Philosophy of Modern Physics. Part B: Studies in History and Philosophy of Modern Physics, v. 41, n. 3, p. 208-217, 2010. doi: 10.1016/j. shpsb.2010.06.002

61. WYNNE, Brian. SSK's identity parade: signing-up off-and-on. Social Studies of Science, v. 26, n. 2, p. 357-91, 1996. doi: 10.1177/030631296026002007

62. WYNNE, Brian. Strange weather, again: climate science as political art. Theory, Culture \& Society, v. 27, n. 2-3, p. 289-305, 2010. doi: $10.1177 / 0263276410361499$

63. WHITEHEAD, Mark; JONES, Rhys; JONES, Martin. The nature of the state: excavating the political ecologies of the modern state. Oxford: Oxford University Press, 2007

Received: Feb. 15, 2019

Accepted: July 01, 2019 